\title{
Customer Satisfaction Management: A Mini Review
}

\author{
Mehrsa Bakhtiyari ${ }^{1}$ \\ ${ }^{1}$ Affiliation not available
}

April 28, 2020

\section{Mehrsa Bakhtiyari 1*}

1 Department of Management, Tehran Markaz Azad University, Tehran, Iran.

* Correspondence: mehrsa.bakhtiari@yahoo.com;

\begin{abstract}
Customer satisfaction is a measure of the level of happiness a customer derives from a product or service provided. Customer satisfaction measurement involves collection of data on information about the level of satisfaction of a customer about a service. It helps improve service delivery and also serves as a tool for performance assessment. This paper reviews existing studies on customer satisfaction measurement as well as the various tools that have been employed to measure customer satisfaction.
\end{abstract}

Keywords: management; customer satisfaction measurement; performance; service

\section{Introduction}

Customer satisfaction measurement is a process of obtaining data which gives information about the level of satisfaction of a customer about a service. This tool uses questionnaires to gather information about customers' level of satisfaction as regards their service experience. It also involves structured survey questions where customers evaluate their levels of satisfaction using predetermined scales or open-ended questions containing information about the different areas of satisfaction related to the service(s) provided.

Customer satisfaction measurement helps improve service delivery. This process enhances customer satisfaction both in the short and long run. The foundation of customer satisfaction measurement is based on several theories in business, marketing and management. One of such theories is the disconfirmation model, which describes satisfaction as the association between expectations and perceived performance [1-2]. Due to the emergence of customer satisfaction measurement from business and marketing fields, this is a common tool in the commercial industry. This tool is utilized in marketing to enhance business performance. This is a vital tool because customer satisfaction is the ultimate aim of any venture due to the fact that satisfied customers are most likely to patronize again or even recommend the product to others. This tool customer helps to understand customers' needs, behaviours and motivations. It also helps firms to appreciate customers' values as this varies from one customer to another. Ultimately, customer satisfaction is a "win win" situation for both the service providers and customers.

Customer satisfaction measurement is not only applied in the commercial sector. Government agencies also use this tool to assess their performance as well as improve their quality of service. Public services which are noted for using this tool include health and transport industries. Despite this tool been common, some sectors of government have yet to utilize this valuable apparatus.

In this paper, existing studies on customer satisfaction measurement as well as the various tools that have been employed to measure customer satisfaction are reviewed.

Customer Satisfaction Measurement as a Tool for Engagement and Empowerment 
Customer satisfaction measurement serves a platform for engaging with and obtaining information from customers. This serves as the customer's voice in the organization. In a study by Rapp and Poertner [3], they highlighted customer-centered approach to service delivery as a major challenge faced by service providers. To overcome this, sourcing opinions from customers have been suggested [4]. Therefore, customer satisfaction measurement aims to achieve a customer-centered service delivery.

Customer satisfaction does not only involve the process of gathering information from customers, but also an avenue for customer empowerment [5]. It gives customers some sort of control over the quality of service they pay for. In a study conducted in the UK, customer satisfaction measurement was described as a means of focusing on the customer as well as customer experience [6]. Hence, the needs of customers are better addressed.

\section{Customer Satisfaction Measurement as a Tool for Service Improvement}

Customer satisfaction measurement provides ensures service improvement. Organizations with the necessary information about customer satisfaction can utilize it to improve their services as well as enhance effective management of customers' expectations. This is especially useful for improving the areas that are more important to customers [6], thereby ensuring that time and resources are properly channeled.

\section{Customer Satisfaction Measurement as a Tool for Performance Management}

Apart from been used as a tool for engagement and obtaining information as well as for enhancing service delivery, customer satisfaction measurement also serves as a vital tool for performance management. Customer satisfaction data gives insight on the performance of an organization as it relates to their service, department or employees. If done consistently, a clearer stand on the general performance of an organization regarding customer service will be better evaluated [6]. Data obtained from this tool can also be used to monitor contract completion as well as level of accountability. Information about service performance helps to build customer trust and also that of potential investors when sourcing for more funds.

\section{Measurement of Customer Satisfaction}

Knowledge about the determinants of service quality is important in order to specify, measure, control and achieve customer satisfaction [7]. It also helps service providers to focus on what is most important when addressing customer satisfaction. However, differences exist between in the drivers of service quality and limited agreement on what are the major dimensions of satisfaction [8].

According to a study by Harvard Medical School, they highlighted eight major determinants for measuring patient satisfaction as follows:

* access to care

* information, communication and education

* respect for patient values, preferences and expressed needs

* coordination and integration of care

* physical comfort

* emotional support and alleviation of fear and anxiety

* involvement of family and friends

* transition and continuity.

The National Health Service patient survey in England has also adopted this model for conducting its studies [9].

In marketing, several determinants of customer satisfaction have been proposed. Parasuraman et al. developed ten determinants of service quality [10]. This has been further pruned down to five based on the 
refined RATER instrument [11] as follows:

* reliability (provision of dependable services)

* assurance (trust) * tangibles (physical facilities, equipment, staff and communication materials)

* empathy (care and personalized service to customers)

* responsiveness (providing timely services to customers).

A research conducted by Johnson [7] developed eighteen determinants of quality of service which are given as follows:

* attentiveness/helpfulness

* responsiveness

* care

* availability

* reliability

* integrity

* friendliness

* courtesy

* communication

* competence

* functionality

* commitment

* access

* flexibility

* aesthetics

* cleanliness/tidiness

* comfort

* security.

In another research carried out in the UK on customer satisfaction in the public sector, they identified five major determinants of satisfaction and dissatisfaction accounting for $67 \%$ variation in overall satisfaction [11]. They include the following:

* delivery

* timeliness

* professionalism

* information

* staff attitude.

The Common Measurement Tool (CMT), was developed by the Institute for Citizen-Centered Service and used by public service organizations in Canada to assess customer satisfaction [12]. In their model, the following key determinants of service quality include: 
* timeliness

* ease of access

* outcome

$*$ staff performance.

A survey was conducted by Essex et al. to assess the level of satisfaction of consumers of mental health services [13]. They highlighted four factors associated with overall satisfaction as follows:

* satisfaction with services

* acceptability of clinician

* impact of services

* dignified treatment.

Several tools can be used to assess customer satisfaction including informal conversations with customers, complaint forms, questionnaires, interviews etc. Different factors should be considered when selecting the most appropriate method of assessing customer feedback such as timing of the survey, sampling bias, customer benefit, confidentiality, customer expectation and experiences, social and cultural background, capacity to respond, carer involvement and response bias.

\section{Conclusion}

In this article, the concept of customer satisfaction measurement and its importance to both private and government ventures have been highlighted. The determinants of service quality as suggested by various studies were also discussed. In conclusion, customer satisfaction measurement, if well implemented will ensure that both customer and service providers have a fruitful relationship.

\section{References}

1. Buttle, F. Servqual: review, critique, research agenda. Eur J Mark. 1996, 30 , 8-32.

2. Aigbavboa, C.; Thwala, W. In A theoretical framework of users' satisfaction/dissatisfaction theories and models , 2nd International Conference on Arts, Behavioral Sciences and Economics Issues (ICABSEI'2013) Dec, 2013; pp 17-18.

3. Rapp, C. A.; Poertner, J. Moving clients center stage through the use of client outcomes. Admin Soc Work 1988, $11,23-38$.

4. Baronet, A.-M.; Gerber, G. J. Client satisfaction in a community crisis center. Eval Program Plann. 1997, $20,443-453$.

5. Larsen-Rife, D.; Brooks, S. The importance of family engagement in child welfare services. Northern California Training Academy 2009 .

6. Adebanjo, D. Understanding customer satisfaction-a UK food industry case study. $\mathrm{Br} F o o d ~ J 2001,103$ , 36-45.

7. Johnston, R. The determinants of service quality: satisfiers and dissatisfiers. Int J Serv Ind Manag 1995, $6,53-71$.

8. Pearse, J. Review of patient satisfaction and experience surveys conducted for public hospitals in Australia: A Research Paper for the Steering Committee for the Review of Government Service Provision.St Leonards, Australia: Health Policy Analysis Pty Ltd2005.

9. Owen, A. G.; Samsa, P. D.; Fildes, D. L.; Grootemaat, P. E.; Eagar, K. Measuring outcomes in community care: an exploratory study.2010 . 
10. Parasuraman, A.; Zeithaml, V. A.; Berry, L. L. A conceptual model of service quality and its implications for future research. J Mark1985, 49, 41-50.

11. Ipsos, M. Public service reform: Measuring \& understanding customer satisfaction. Retrieved on November 2002, 1, 2013.

12. Verdegem, P.; Verleye, G. User-centered E-Government in practice: A comprehensive model for measuring user satisfaction. Government information quarterly 2009, 26 , 487-497.

13. Essex, D. W.; Fox, J. A.; Groom, J. M. The development, factor analysis, and revision of a client satisfaction form. Community Ment Health J. 1981, 17, 226-235. 